\title{
Purification of Raw Material and Biodiesel Products from Waste Oil with Deep Eutetic Solvent (DES)
}

\author{
Sahrul Effensi ${ }^{1}$ Aida syarif ${ }^{1, *}$ Irawan Irawan ${ }^{1}$

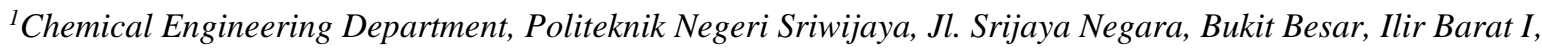 \\ Palembang 30139, South Sumatera, Indonesia \\ *Corresponding author.Email: aida_syarif@yahoo.co.id
}

\begin{abstract}
Biodiesel is a substitute for diesel fuel which is produced from the synthesis of various plant or animal oils. Waste cooking oil is an example of plant oil that can be used as raw material to make biodiesel. To prevent saponification at the trans-esterification stage it use Deep Eutectic Solvent (DES) as purified The high content of Free Fatty Acids (FFA) in waste cooking oil. The purpose of this study was to determine the effect of variations in the molar ratio, reaction time and stirring speed of the DES synthesis on the free fatty acid content of biodiesel. DES was made from a mixture of choline chloride and ethylene glycol with a molar ratio of 1:1, 1:2, $1: 3,1: 4$, and 1:5, with variations in reaction time of 15 minutes and 30 minutes, and variations in stirring speed of $200 \mathrm{rpm}$ and $300 \mathrm{rpm}$ at $50 \mathrm{oC}$. The FFA content of waste cooking oil as raw material for biodiesel is $8.323 \%$. The results showed that the smallest decrease in FFA levels was up to $0.55 \%$ at a 1:2 molar ratio, a reaction time of 30 minutes and a stirring time of $300 \mathrm{rpm}$.
\end{abstract}

Keywords: FFA, DES, Waste Oil, Biodiesel

\section{INTRODUCTION}

The development of the era of globalization followed by rapid industrial and economic growth, as well as an increase in population has led to a significant increase in the amount of energy consumption. Data from the Agency for the Assessment and Application of Technology (BPPT) in the 2016 Indonesia Energy Outlook states that the highest contributors to the energy consumption figure are industry (48\%) and transportation (35\%) which still rely on non-renewable energy sources such as coal, gas and petroleum, while the use of non-oil fuels or biofuels from year to year is increasing but in 2014 it only reached 9\%. Therefore, currently a lot of research is being carried out related to the development of alternative energy to increase the production and consumption of these biofuels [1]

One of the alternative fuels that has been widely developed is biodiesel. Biodiesel is a bioenergy made from vegetable oil through a transesterification, esterification, or esterification-transesterification process. Biodiesel is a fuel that is friendly to the environment, does not contain hazardous materials such as $\mathrm{Pb}$, is biodegradable, and has lower exhaust emissions than diesel fuel emissions. Biodiesel has a high lubricating effect so that it can extend engine life and has a high cetane number, which is greater than 50 [2]).

Deep Eutectic Solvents (DES) are mixing component solvents and its making from quaternary ammonium salt with hydrogen bond donor. It mixed together in the right ratio to get the eutectic point. DES was first described by Abott et al for a mixture of choline chloride $(\mathrm{CHCl})$ and urea with a 1:2 molar ratio [3] DES is generally used as a solvent in the extraction process. According to Zhang et al (2012), DES can be used to separate biodiesel from FFA, unreacted oil, and unsaponifable matter.

Waste cooking oil is cooking oil which it has been used for frying more than three times, it can be categorized as waste because it will be dangerous for the environment and can cause a number of diseases. The sustainable use of waste cooking oil can damage human health, cause cancer, deposition of fat in blood vessels, and the subsequent consequences can reduce intelligence [4]

Utilization of waste cooking oil into biodiesel can reduce waste cooking oil and optimize its use. In addition, DES solvent is a good solution to reduce production costs because the raw material is cheap and 
reduces environmental pollution because it is non-toxic and biodegradable.

\section{RESEARCH METHODS}

The research was conducted at the Laboratory of Chemical Engineering Department, Sriwijaya State Polytechnic, Palembang. The waste cooking oil came from private household waste, Choline Chloride $(\mathrm{ChCl})$ (99.99\%) was purchased from Smartchem (Medan, Indonesia), Ethylene Glycol (99.8\%) was purchased from Bratachem (Palembang, Indonesia).

In this study, a mixture of Choline Chloride and Ethylene Glycol (EG) was used with a molar ratio of 1:2. DES was synthesized by stirring and heating at a temperature of $50 \mathrm{oC}$, stirring speed of $300 \mathrm{rpm}$, and a time of 30 minutes.

Waste cooking oil is reduced in the content of Free Fatty Acid (FFA) through liquid-liquid extraction using DES. The reduction of FFA was carried out using a variation of the molar ratio between waste cooking oil and DES of 1:1, 1:2, 1:3, 1:4. Variations in stirring speed of $150 \mathrm{rpm}$ and $300 \mathrm{rpm}$ and variations of stirring time of 60 minutes and 120 minutes were used at a temperature of $60 \mathrm{oC}$.

The transesterification step was carried out with a molar ratio of 1:40:100 for the catalyst compared to methanol compared to waste cooking oil. $\mathrm{KOH}$ is used as a catalyst in the transesterification process on a hot plate at a temperature of $60 \mathrm{oC}$ for 3 hours at a speed of $800 \mathrm{rpm}$ then separates the crude biodiesel that has been produced from methanol and the catalyst using a separating funnel by leaving it for 24 hours and washing the crude biodiesel using DES with a mass ratio 0.5:1 for 45 minutes.

Analysis of the characteristics of the liquid fuel tested is the analysis of Density (ASTM D-1298), Viscosity (ASTM D-1298), Flash Point (ASTM D-93) and Cetane Number.

The stages carried out in this study can be seen in Figure 1

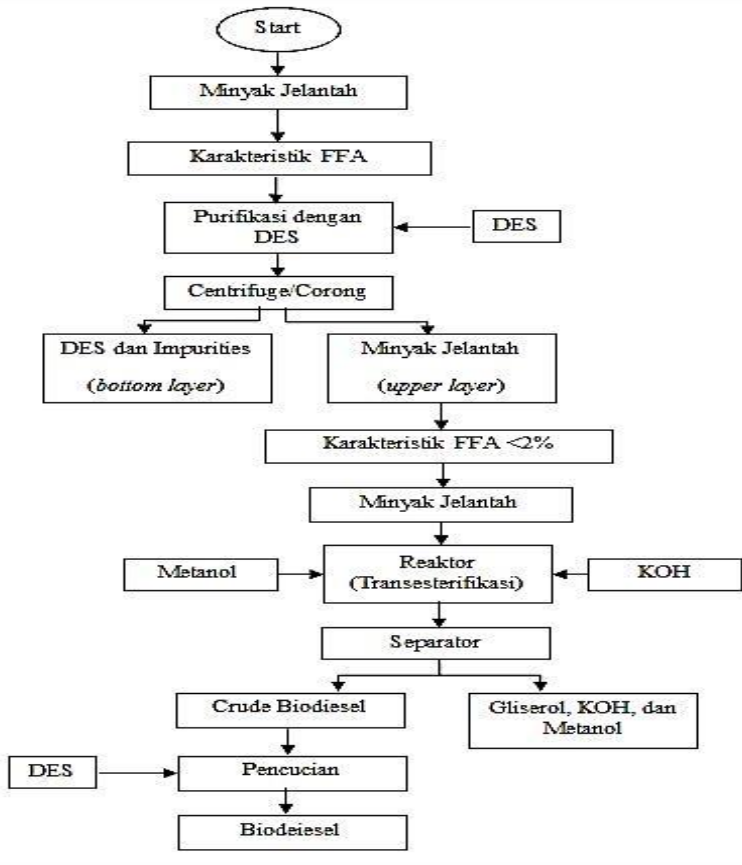

Figure 1. Flow Diagram of Process

\section{RESULTS AND DISCUSSION}

\subsection{Characteristic of DES}

DES from a mixture of $\mathrm{ChCl}$ and $\mathrm{EG}$ produced has a liquid form and is clear in color and has a density of $1.1702 \mathrm{gr} / \mathrm{cm} 3$. These results indicate that DES can be used as a solvent for the extraction process because it is in the density range of $1.1 \mathrm{gr} / \mathrm{cm} 3-2.4 \mathrm{gr} / \mathrm{cm} 3$ [6]

\subsection{Reduction of Free Fatty Acid (FFA) in Cooking Oil}

Analysis of the effect of the molar ratio of waste cooking oil (MJ) and DES, speed, and stirring time on the extraction process, obtained that the FFA content in waste cooking oil decreased to $0.55 \%$, whereas waste cooking oil that was not extracted had a concentration of $8.32 \%$. The results of the analysis can be seen in the graphs presented in Figure 2 and Figure 3.

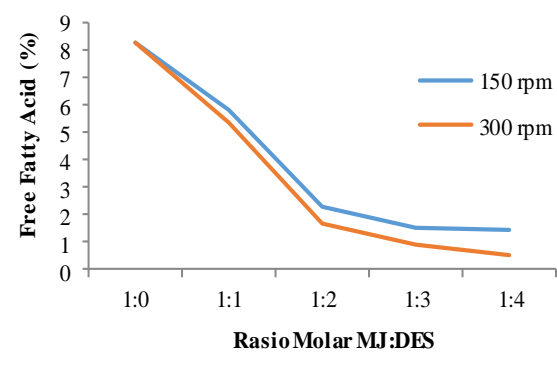

Figure 2. Graph of the relationship FFA between Ratio Molar Of DES 
In figure 2 is a graph showing the effect of the molar ratio of waste cooking oil and des as well as the stirring speed. It was seen that there was a decrease in ffa content in waste cooking oil that had been extracted using des. The decrease occurred along with the increasing number of des in the mixture.

The best reduction was obtained using the mj:des ratio of 1:4. The ffa compound has a hydroxyl group that can interact with des, while the methyl ester which is the main component of biodiesel does not have $h+$ ions that can bind to des. The greater the number of des in the ratio will increase the possibility of hydrogen bonds between des and ffa, so that the ffa contained can decrease.

Stirring speed also has an influence, where the best ffa reduction is at a speed of $300 \mathrm{rpm}$ at a stirring time of 120 minutes. Stirring is done to increase the contact between the substance to be dissolved with the solvent to obtain a high degree of homogeneity.

Stirring speed that is too low causes the contact between substances not to run optimally. The faster the stirring rotation will increase the heat transfer that occurs at a certain time and the greater the contact of the material with the solvent, the results obtained will increase. However, the use of rotation that is too fast causes the contact between the material and the solvent to be shorter. So that before the material and solvent bond completely, the bond is released again [5]

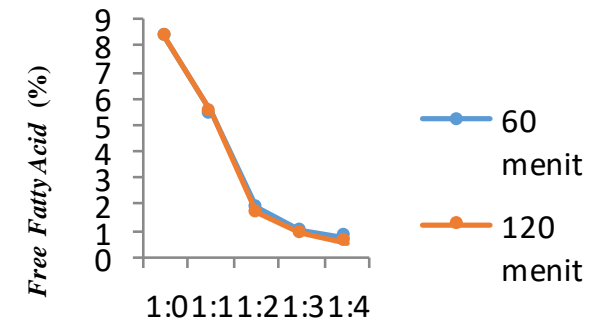

Rasio Molar MJ:DES

Figure.3. Graph of the relationship between FFA and molar DES

The duration of stirring (time) also has an effect on the process of decreasing the levels of Free Fatty Acid of waste cooking oil although it shows a not too significant difference. Stirring time for 60 minutes can reduce the smallest FFA that is $0.75 \%$ and stirring for 120 minutes can reduce the smallest FFA that is $0.55 \%$.

The longer the process of stirring waste cooking oil and DES, the higher the level of FFA which will be bound by DES with a temperature that must be maintained at $60^{\circ} \mathrm{C}$ so that oil cracking does not occur. This is because the longer the washing time, the greater the intensity of the reaction between DES and the FFA content contained in DDRBO.
Niawati (2017) concluded in her research that the longer the extraction time, the higher the \% FFA removal obtained. The high \% FFA removal indicates that the impurities extracted by DES are getting bigger. In the research of [7]. also said that the conversion of FFA will increase with the longer extraction time.

\subsection{Characteristics of Biodiesel from the lowest Free Fatty Acid Level of Cooking Oil}

Table 1. Characteristic of Biodiesel from The Lowest FFA

\begin{tabular}{lcc}
\hline \multicolumn{1}{c}{ Parameter } & $\begin{array}{c}\text { Standar SNI } \\
\text { Biodiesel }\end{array}$ & $\begin{array}{c}\text { Hasil } \\
\text { Penelitian }\end{array}$ \\
\hline Densitas $(\mathrm{kg} / \mathrm{m} 3)$ & $850-890$ & 869,12 \\
Viskositas $\left(\mathrm{mm}^{2} / \mathrm{s}\right)$ & $2,3-6,0$ & 4,6306 \\
Titik Nyala $\left({ }^{\circ} \mathrm{C}\right)$ & Min 100 & 183,30 \\
Angka Setana & Min 51 & 49,3 \\
\hline
\end{tabular}

\section{CONCLUSION}

Deep Eutectic Solvent (DES) in the liquid-liquid extraction process in waste cooking oil as extractor has been shown to be able to reduce Free Fatty Acid (FFA) levels by up to $0.55 \%$. The best reduction in FFA was obtained at the MJ:DES molar ratio of 1:4 with a stirring speed of $300 \mathrm{rpm}$ for 120 minutes. The biodiesel yield obtained is close to the SNI Biodiesel Standard 047182-2006. DES is a solvent that is very suitable for liquid-liquid extraction so that further analysis is needed to determine its specific use.

\section{AUTHORS' CONTRIBUTIONS}

By agreement with the team then as AIDA SYARIF Author Respondents

\section{ACKNOWLEDGMENTS}

Thank you to the Sriwijaya State Polytechnic for funding this research.

\section{REFERENCES}

[1] Abdullah, dkk. (2012). Synthesis of Cetane Improver from Castor Oil Biodiesel and Testing on Diesel Engines. Science and Applied Chemistry. 6(1):46-58.

[2] Aziz, I., Nurbayati, S., dan Ulum, B. (2011). Manufacturing of biodiesel products from waste cooking oil by esterification and transesterification. Valensi. 2 (3):443-448. 
[3] Abri, A., dkk. (2019). Spectral and thermophysical properties of some novel deep eutecticsolvent based on 1-menthol and their mixtures with ethanol. Journal of Molecular Liquids. 285 (2019):477-487.

[4] Aini, H. Q. dan Heryantoro, R. P. (2017). Purification of biodiesel from rice bran oil using a deep eutectic solvent: the effect of the molar ratio of choline chloride and ethylene glycol on the purity and yield of biodiesel. Skripsi. Faculty of Industrial Technology, Sepuluh Nopember Institute of Technology, Surabaya.

[5]. Alamsyah, M., Ifa. L., dan Kalla, R. (2017). Purification of waste cooking oil by adsorption process. Journal of Chemical Process Engineering. 2 (2):22-26.

[6] Fischer, V. dan Kunz W. (2015). Properties of Sugar-Based Low-Melting Mixture.Journal Molecular Physics. 112(1):9-10 .

[7] Ardiani, F. dan Wulanndari, T. G. (2017). Ethylene Glycol Plant from Ethylene Direct Oxidation Process with Air Continued

[18] Bratajaya, S. B. Y. (2020). Pyrolysis of Reject Plastic into Oil Fuel Using Coal Fly Ash and Natural Zeolite Catalyst. Skripsi. Department of Chemical Engineering, Faculty of Engineering, University of North Sumatra.

[9] Daely, A. T. I. (2020). Utilization of dimentholbased hydrophobic deep eutectic solvents in the removal of pesticides on fresh fruit and vegetables. USU Journal of Chemical Engineering. 9 (1):7-10.
[10] Atadashi, M. (2015). A review purification of crude biodiesel using dry washing and membrane technology. Alexandria Engineering Journal. 54 (4):1265-1272.

[11]. Dewi, K. H., dkk. (2010). Extraction of Sea Cucumber (Holothuria Scabra) as a Source of Testosterone at Various Stirring Speeds and Lengths. Proceedings of the National Seminar on Chemical Engineering "Kejuangan". Yogyakarta.

[12] Dyah, P. S. dan Sukaryo. (2018). Characteristic Test of Biodiesel Based on Fish Offal Waste Processed Using Microwaves. Metana. 14(2):37-42.

[13] Erni, dkk. (2017). Making Biodiesel from Used Cooking Oil by Transesterification Process Using KOH. Catalyst. Skripsi. Industrial Chemical Engineering, Vocational Faculty, Sepuluh Nopember Institute of Technology, Surabaya.

[15] Frauenkron, M., dkk. (2012). Ethanolamines and Propanolamines. Encyclopedia of Industrial Chemistry. 13:405-428.

[15]. Halid, S., dkk. (2016). Processing waste cooking oil into biodiesel. Entropy Journal. 11 (2):204-214.

[16] Haryanto, A., dkk. (2015). Biodiesel production from transesterification of used cooking oil with the help of microwaves: the effect of power intensity and reaction time on the yield and characteristics of biodiesel. Jurnal. 35

(2):234-240 